\title{
Effects of Some Non-Steroidal Anti-Inflammatory Drugs and Other Agents on Cyclooxygenase and Lipoxygenase Activities in Some Enzyme Preparations
}

\author{
Katsuhiko MIYAZAWA, Yayoi IIMORI, Masao MAKINO, \\ Takashi MIKAMI and Katsuhiko MIYASAKA \\ Pharmacological Research Department. Teikoku Hormone Mfg. Co., Ltd. \\ Shimosakunobe 1604. Takatsu-ku. Kawasaki 213. Japan
}

Accepted March 4. 1985

\begin{abstract}
The inhibiting influences of some non-steroidal anti-inflammatory drugs (NSAIDs) and other agents on cyclooxygenase (CO) and lipoxygenase (LO) activities in some enzyme preparations were investigated. Washed rat platelets (CO and 12-LO), rat polymorphonuclear leukocytes (PMNs, CO and 5-LO), rat renal medulla homogenate (CO), and purified soybean LO (15-LO) were used as enzyme preparations. The 1 C50 values of drugs on the enzyme activities were determined in each preparation. In addition, the inhibitory activities of the drugs on the generation of chemiluminescence from PMNs stimulated by phorbol myristate acetate were tested. NSAIDs (indomethacin, ketoprofen and phenylbutazone) showed a selective inhibition of $\mathrm{CO}$ in each preparation, but benoxaprofen inhibited both enzymes, especially in PMNs. BW755C, 1-phenyl-3-pyrazolidone (phenidone), toluene-3,4-dithiol (dithiol). 6-ethoxy-1.2-dihydro-2.2.4-trimethylquinoline (ethoxyquin) and acetone phenylhydrazone (APH) inhibited both enzyme activities. Nordihydroguaiaretic acid (NDGA) showed a relatively selective inhibition of LO in all the preparations used. APH inhibited soybean 15-LO markedly compared with the other enzymes tested. Ethoxyquin inhibited COs more markedly than LOs, and with regard to LO inhibition, it inhibited 5-LO in PMNs markedly. BW755C, phenidone, ethoxyquin, NDGA, APH and dithiol, which strongly inhibited 5 -LO. showed an inhibitory activity on the generation of chemiluminescence from PMNs activated with phorbol ester.
\end{abstract}

Unsaturated fatty acids, especially arachidonic acid, are metabolized not only by cyclooxygenase (CO) but also by lipoxygenase (LO) in various cells and tissues. Since the inhibition of $\mathrm{CO}$ was proposed as the common mechanism for the anti-inflammatory action of some non-steroidal antiinflammatory drugs (NSAIDs) by Vane (1). there have been many reports which support his hypothesis. However, the anti-inflammatory action of NSAIDs is not always explained solely by the inhibition of $\mathrm{CO}(2$, 3).

Recently, leukotriene $B_{4}$, one of the LO products of arachidonic acid, has been reported to increase vascular permeability in combination with polymorphonuclear leukocytes (PMNs) and $\mathrm{PGE}_{2}(4,5)$, to show a potent chemokinetic (6) and chemotactic activity (7) for PMNs, and to stimulate lysosomal enzyme secretion for PMNs (8). Leukotrienes $\mathrm{C}_{4}$ and $\mathrm{D}_{4}$, other LO products of arachidonic acid, have been reported to increase vascular permeability (9). These findings suggest that $L O$ products as well as CO products of arachidonic acid may be involved in the initiation and development of acute inflammatory reactions. In general. NSAIDs have no inhibitory activity on LO. although there are some exceptions like benoxaprofen which inhibits the LO of rabbit PMNs (10). 
Recently, a variety of $L O$ inhibitors have been reported, and most of them also have an inhibitory activity on $\mathrm{CO}$. Though there are many reports about inhibitory effects of various drugs including NSAIDs, antioxidants and polyunsaturated fatty acids, etc. on the arachidonic acid cascade, it is difficult to compare the data obtained from different reports, because the enzyme preparations used in these reports differ from each other. in this study, to elucidate the characteristics of inhibitory effects of some typical antiinflammatory drugs and antioxidants on the arachidonic acid cascade, we compared these drugs to each other with regard to their effects on arachidonic acid metabolism. For this purpose. we used 3 different $\mathrm{CO}$ systems and 3 different LO-systems: washed rat platelets ( $\mathrm{CO}$ and $12-\mathrm{LO}$ ) and rat PMNs (CO and 5-LO) as intact cell systems and rat renal medulla homogenate (CO) and purified soybean LO (15-LO) as cell free systems.

In addition, we tested the influences of the drugs on the generation of chemiluminescence (CL) from activated PMNs to investigate the relationship between their effects on the arachidonic acid cascade and those on the generation of $\mathrm{CL}$.

\section{Materials and Methods}

The main chemicals used in the experiments were as follows: $\left[1-{ }^{14} \mathrm{C}\right]$-arachidonic acid (55 mCi/mmol, 98-99\% purity) (New England Nuclear, Boston. MA. U.S.A.), arachidonic acid (grade 1, approx. 99\% purity). 4 $\beta$-phorbol $12 \beta$-myristate $13 \alpha$ acetate (PMA), I-epinephrine bitartrate, lambda carrageenan (Sigma, St. Louis, MO. U.S.A.), indomethacin (Sumitomo Chemical, Osaka, Japan), phenylbutazone (Leisinger. Corona/Ti, Switzerland), 1-phenyl-3-pyrazolidone (phenidone), glutathione (Wako, Osaka. Japan), 6-ethoxy-1,2-dihydro-2,2,4trimethyl-quinoline (ethoxyquin) (Tokyo Kasei, Tokyo, Japan), nordihydroguaiaretic acid (NDGA), toluene-3,4-dithiol (dithiol). gelatin fine powder (Nakarai, Kyoto, Japan), and calcium ionophore A23187 (CalbiochemBehring. La Jolla, CA. U.S.A.). BW755C, ketoprofen, benoxaprofen and acetone phenylhydrazone (APH) were synthesized in our laboratory. Soybean lipoxydase [EC 1.13.11.12] type I was purchased from Sigma, St. Louis, MO, U.S.A.. Precoated silica gel 60 plastic sheets for thin layer chromatography were products of $E$. Merck. Darmastadt, FRG. In this study, propylene glycol (less than $2 \%$ at the final concentrations) was used to dissolve NDGA and dithiol and had no effect on enzyme activities. All other drugs were dissolved with equimolar $\mathrm{NaOH}$ or $\mathrm{HCl}$ in the buffer used in each assay.

$\mathrm{CO}$ and 12-LO activities in platelets: Rat blood containing 0.1 volume of $100 \mathrm{mM}$ EDTA-saline, $\mathrm{pH}$ 7.4, was centrifuged at $250 \times \mathrm{g}$ for $10 \mathrm{~min}$. Platelet-rich plasma was collected by pipetting and then centrifuged at $2.000 \times \mathrm{g}$ for $10 \mathrm{~min}$. Cells were washed with buffer $(50 \mathrm{mM}$ Tris- $\mathrm{HCl}, 100 \mathrm{mM} \mathrm{NaCl}$. $1 \mathrm{mM}$ EDTA, $\mathrm{pH}$ 7.4) and suspended in the same buffer to a concentration of $1 \times 10^{9}$ cells $/ \mathrm{ml}$ (washed platelet suspension). One hundred $/ \mathrm{l}$ of $0.5 / 2 \mathrm{Ci} / \mathrm{ml}\left[1-{ }^{14} \mathrm{C}\right]$-arachidonic acid $(55 \mathrm{mCi} / \mathrm{mmol}) .50$ ul of drug solution and $50 \mu$ of washed platelet suspension were mixed and incubated at $37^{\circ} \mathrm{C}$ for $2 \mathrm{~min}$ with shaking. This enzymatic reaction was stoped by the addition of $0.9 \mathrm{ml}$ of $4 \mathrm{mM}$ citric acid. Arachidonic acid and its metabolites were extracted with $2.4 \mathrm{ml}$ of chloroform/ methanol $(1: 1, v / v)$ and fractionated by thin layer chromatography (TLC) using the following solvent system: chloroform/ methanol/acetic acid/water (90:8:1:0.8, v/v/ $v / v)(11)$. The radioactive areas on the TLC plates detected by autoradiography were scraped into toluene scintillator fluid containing $10 \%$ methanol, and their radioactivities were counted in an Aloka LSC-651 liquid scintillation counter. Both the fractions containing 12-hydroxyeicosatetraenoic acid (HETE) and its intermediary metabolite. 12hydroperoxyeicosatetraenoic acid. (HPETE) were regarded as 12 - LO products. Thromboxane $\mathrm{B}_{2}$ and 12-hydroxy-5,8,10-heptadecatrienoic acid (HHT) fractions were regarded as $\mathrm{CO}$ products.

$\mathrm{CO}$ and 5-LO activities in PMNs: Male Wistar rats weighing 250-350 g were lightly anesthetized with ether and $0.1 \mathrm{ml}$ of $2 \%$ lambda carrageenan in sterile saline was injected into the right pleural cavity using a procedure similar to that described by Hurley 
et al. (12) except that a 26 -gauge needle was used instead of a 22 -gauge lumbar puncture needle. After $4 \mathrm{hr}$, pleural exudate was collected and centrifuged at $250 \times \mathrm{g}$ for $10 \mathrm{~min}$. Cells were suspended in $17 \mathrm{mM}$ Tris-HCl ( $\mathrm{pH} 7.2$ ) containing $0.75 \% \mathrm{NH}_{4} \mathrm{Cl}$ to lyse red cells and then centrifuged at $250 \times \mathrm{g}$ for 10 min. Cells were resuspended in $50 \mathrm{mM}$ Tris$\mathrm{HCl}$ (pH 7.4) containing $100 \mathrm{mM} \mathrm{NaCl}$ to a concentration of $1.6 \times 10^{6}$ cells $/ \mathrm{ml}$. Fifty $\mu l$ of $2.0 \% \mathrm{Ci} / \mathrm{ml}\left[1-{ }^{14} \mathrm{C}\right]$-arachidonic acid. 50 ul of $2 u \mathrm{M}$ calcium ionophore $\mathrm{A} 23187$ and 50 al of drug solution were mixed. These three solutions were prepared with $50 \mathrm{mM}$ Tris- $\mathrm{HCl}(\mathrm{pH} 7.4$ ) containing $100 \mathrm{mM} \mathrm{NaCl}$ and $1.33 \mathrm{mM} \mathrm{CaCl}_{2}$. Then $50 \mu$ of PMN suspension was added to the mixture and incubated at $37^{\circ} \mathrm{C}$ for $2 \mathrm{~min}$. The subsequent procedures were the same as in the assay for platelet enzymes except for the solvent system: diethylether/hexane/acetic acid (30: 20:1, $v / v / v)$. Leukotriene $B_{4}$ and 5-HETE fractions were regarded as 5 -LO products, and $\mathrm{HHT}$ was regarded as a $\mathrm{CO}$ product.

15-LO activity of purified soybean lipoxygenase: Soybean 15-LO activity was measured by the procedure described by Knippel et al. (13), with some modifications. Soybean lipoxydase $(150 \mathrm{U} / \mu \mathrm{g}$ protein) was dissolved in $0.15 \mathrm{M}$ potassium phosphate buffer $(\mathrm{pH} \mathrm{8.0)}$ to a concentration of $50 \mu \mathrm{g} /$ $\mathrm{ml}$. One hundred al of drug solution and $100 \mu$ of enzyme solution were mixed and pre-incubated at room temperature for 10 min. Then, $100 \mu \mathrm{l}$ of $0.4 \mu \mathrm{Ci} / \mathrm{ml}\left[1-{ }^{14} \mathrm{C}\right]$ arachidonic acid was added and incubated at room temperature for $10 \mathrm{~min}$. One $\mathrm{ml}$ of $n$-hexane/diethylether (49:1, v/v) was added to stop the reaction, and unreacted arachidonic acid was extracted into the organic phase. The organic and the aqueous layers were separated by freezing the latter on dry ice-acetone, and the radioactivity in each layer was measured in a liquid scintillation counter. Unreacted arachidonic acid was present in the organic phase, and LO products were in the aqueous phase. The conversion rate of arachidonic acid to LO products was calculated

$\mathrm{CO}$ activity in renal medulla homogenate: CO activity in renal medulla homogenate was measured using a procedure similar to that described by Baumann et al. (14). Male Wistar rats weighing 250-300 g were decapitated, and the kidneys were immediately removed. Then, the inner medulla was excised, frozen under liquid nitrogen and stored at $-70^{\circ} \mathrm{C}$. The medulla was homogenized in the cold in $0.1 \mathrm{M}$ potassium phosphate buffer ( $\mathrm{pH}$ 8.0) containıng 1.6 $\mathrm{mg} / \mathrm{ml}$ glutathione, at a protein concentration of $15 \mathrm{mg} / \mathrm{ml}$. Twenty-five $/ 4$ of $1.46 \mathrm{mg} / \mathrm{ml}$ I-epinephrine bitartrate, $25 \mathrm{zl}$ of $0.4 \mathrm{mM}$ unlabeled arachidonic acid, $50 \mu$ of 0.5 $\mu \mathrm{Cl} / \mathrm{ml} \quad\left[1-{ }^{14} \mathrm{C}\right]$-arachidonic acid, $50 \mu \mathrm{l}$ of drug solution and $50 / 2$ of medulla homogenate were mixed and incubated at $37^{\circ} \mathrm{C}$ for $30 \mathrm{~min}$ with shaking. The reaction was stopped by the addition of $0.1 \mathrm{ml}$ of ethanol and unreacted arachidonic acid was removed by extracting twice with $0.6 \mathrm{ml}$ of $n$-hexane/ethyl acetate $(2: 1, v / v)$. The radioactivity of whole metabolites in the aqueous phase which consisted mainly of $\mathrm{PGE}_{2}$ was counted in a liquid scintillation counter.

Measurement of chemiluminescence $(\mathrm{CL})$ generated from PMNs: The procedure for preparing the PMN suspension was the same as described above. except that the final concentration of PMNs was $1 \times 10^{8}$ cells $/ \mathrm{ml}$. Hanks' balanced salt solution $(\mathrm{pH} 7.4)(9.7$ ml) containing $1 \%$ gelatin. $0.1 \mathrm{ml}$ of $200 \mu \mathrm{g} /$ $\mathrm{ml} \mathrm{PMA}$ in $50 \%$ dimethylsulfoxide and $0.1 \mathrm{ml}$ of drug solution in $50 \mathrm{mM}$ Tris- $\mathrm{HCl}(\mathrm{pH} 7.4)$ containing $100 \mathrm{mM} \mathrm{NaCl}$ were mixed in a vial. Immediately after the addition of $0.1 \mathrm{ml}$ of PMN suspension, the $C L$ generation from activated PMNs was counted in a liquid scintillation counter (Aloka LSC-651) for 9 min. In this measurement, the counter was set at the following conditions: tritium channel, coincidence mode was changed to the summation mode. $0.1 \mathrm{~min}$ repeat. Total counts in 9 min (it took 9 min for 30 cycles of 0.1 min count and data output) was assumed to be the amount of CL generated in the reaction.

\section{Results}

IC50 values for the drug inhibition of $\mathrm{CO}$ and LO activities are shown in Table 1. NSAIDs except benoxaprofen. i.e. indomethacin, ketoprofen and phenylbutazone showed a selective inhibition of $\mathrm{CO}$ in each 
Table 1. The IC50 ( $/ \mathrm{M})$ for drug inhibition of cyclooxygenase (CO) and lipoxygenase (LO) activities

\begin{tabular}{|c|c|c|c|c|c|c|}
\hline \multirow[b]{2}{*}{ Drugs } & \multicolumn{6}{|c|}{ Enzymes } \\
\hline & $\begin{array}{l}\mathrm{PL} \\
\mathrm{CO}\end{array}$ & $\begin{array}{l}\text { PMNs } \\
\text { CO }\end{array}$ & $\begin{array}{l}\text { R. Med. } \\
\text { CO }\end{array}$ & $\begin{array}{l}P L \\
12-L O\end{array}$ & $\begin{array}{l}\text { PMNs } \\
5-L O\end{array}$ & $\begin{array}{l}\text { Soybean } \\
15-\mathrm{LO}\end{array}$ \\
\hline Indomethacin & $5.90=0.25$ & $4.78=0.94$ & $5.07 \pm 0.57$ & $916 \pm 130$ & $332 \pm 10$ & N.E. $(1000)$ \\
\hline Ketoprofen & $1.45 \pm 0.25$ & $0.58 \pm 0.17$ & $2.20 \pm 0.70$ & N.E. $(5000)$ & N.E. $(1500)$ & N.E. $(3000)$ \\
\hline Phenylbutazone & $79.3 \pm 27.2$ & $15.7 \pm 2.1$ & $20.9 \pm 2.7$ & N.E. (1500) & N.D. & N.E. $(1000)$ \\
\hline Benoxaprofen & $2360 \pm 440$ & $19.3 \pm 0.8$ & $767 \pm 137$ & $4440 \pm 690$ & $171 \pm 26$ & N.E. $(3000)$ \\
\hline BW755C & $21.6 \pm 1.0$ & $11.6 \pm 6.6$ & $12.1 \pm 1.6$ & $66.2 \pm 2.3$ & $55.7 \pm 2.6$ & $38.5 \pm 3.9$ \\
\hline Phenidone & $89.3 \pm 11.2$ & $125 \pm 19$ & $147 \pm 18$ & $66.8 \pm 4.9$ & $24.4 \pm 9.7$ & $7.19 \pm 2.06$ \\
\hline Ethoxyquin & $17.3 \pm 1.0$ & $5.93 \pm 2.20$ & $8.90=2.80$ & N.E. $(1500)$ & $25.3 \pm 4.7$ & $1333 \pm 300$ \\
\hline NDGA & $38.1 \pm 10.2$ & $40.6 \pm 3.8$ & $86.3 \pm 12.8$ & $3.72 \pm 1.15$ & $2.40 \pm 0.75$ & $1.08 \pm 0.34$ \\
\hline $\mathrm{APH}$ & $4.03 \pm 0.50$ & $9.60 \pm 4.37$ & $7.20 \pm 0.40$ & $8.07 \pm 0.47$ & $4.84=0.91$ & $0.12 \pm 0.02$ \\
\hline Dithiol & $6.62 \pm 1.04$ & $26.3 \pm 0.8$ & $43.3 \pm 10.3$ & $20.1 \pm 3.9$ & $24.4 \pm 1.5$ & $219 \pm 99$ \\
\hline
\end{tabular}

The results represent the mean \pm S.E.M. of values obtained from at least 3 experiments. PL.: platelets, PMNs: polymorphonuclear leukocytes. R. Med.: renal medulla homogenate. N.E.: no inhibitory effect at or below the concentration given in parentheses $(\mu \mathrm{M})$. N.D.: not determined, because the maximal inhibition was less than $50 \%$.

preparation, but benoxaprofen inhibited both enzyme activities, especially in PMNs.

Phenylbutazone caused the maximal inhibition (60\%) of $\mathrm{CO}$ in PMNs at $50 \mu \mathrm{M}$, and no further increase in inhibition was seen at concentrations more than $50 \mu \mathrm{M}$. Arachidonic acid metabolism was accelerated at these concentrations (Fig. 1). Phenylbutazone also showed a weak inhibition of 5-LO in PMNs. It was less than $50 \%$, even at the maximal inhibition.

BW755C, phenidone, dithiol, ethoxyquin and APH inhibited both enzyme activities. NDGA caused a relatively selective inhibition of LO in all the preparations used. Ethoxyquin inhibited $\mathrm{CO}$ activities more markedly than LO activities, and with regard to LO inhibition, it inhibited 5-LO in PMNs markedly. APH inhibited $\mathrm{CO}$ and $\mathrm{LO}$ activities to approximately the same extent except for 15-LO which was markedly inhibited. Benoxaprofen inhibited $\mathrm{CO}$ and 5-LO activities in PMNS markedly.

The inhibitory activities of the drugs tested on the CL generation from activated PMNs are shown in Table 2. The mean $\mathrm{cpm}$ of reference controls in 9 min was $3.57 \pm 0.25 x$ $10^{5}$ (mean \pm S.E., $n=4$ ). In this experiment, BW755C, phenidone, ethoxyquin. NDGA, $\mathrm{APH}$ and dithiol, which strongly inhibited 5-LO, showed an inhibitory activity on the generation of $\mathrm{CL}$. On the other hand, NSAIDs

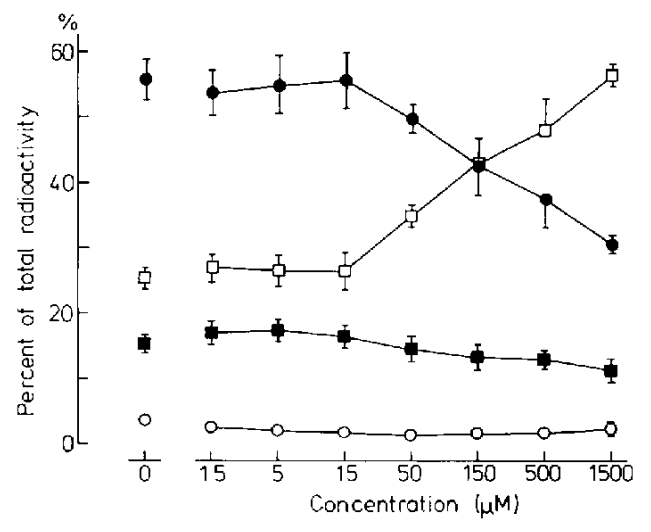

Fig. 1. Effect of phenylbutazone on arachidonic acid (AA) metabolism in PMNs. Values are means \pm S.E.M. obtained from 5 experiments. - $-A A$ fraction: -O- HHT fraction: - - - $\mathrm{LTB}_{4}+5$ HETE fractions; $-\square-$, residual fractions.

had no effect on the CL generation or slightly enhanced it.

\section{Discussion}

Though indomethacin and ketoprofen caused a selective and dose-dependent inhibition of $\mathrm{CO}$ as many reports have shown. the pattern of inhibitory action of phenylbutazone on $\mathrm{CO}$ was somewhat different. The inhibitory effect of phenylbutazone on CO in PMNs reached a plateau $(60 \%$ inhibition) at $50 \mu \mathrm{M}$. Whereas $\mathrm{CO}$ was 
Table 2. The inhibitory activities of various drugs on the generation of chemiluminescence from stimulated PMNs

\begin{tabular}{|c|c|c|c|c|c|}
\hline \multirow[b]{2}{*}{ Drugs } & \multicolumn{5}{|c|}{ Concentrations $(\mu \mathrm{M})$} \\
\hline & 50 & 5 & 0.5 & 0.05 & 0.005 \\
\hline Indomethacin & -16 & & & & \\
\hline Ketoprofen & 0 & & & & \\
\hline Phenylbutazone & 3 & & & & \\
\hline Benoxaprofen & -8 & & & & \\
\hline BW755C & & & 72 & 44 & 12 \\
\hline Phenidone & & 82 & 12 & & \\
\hline Ethoxyquin & & 79 & 20 & 1 & \\
\hline NDGA & 97 & 94 & 73 & 13 & \\
\hline $\mathrm{APH}$ & 93 & 68 & 14 & & \\
\hline Dithiol & 98 & 83 & 22 & & \\
\hline
\end{tabular}

The values represent $\%$ inhibition.

inhibited, arachidonic acid metabolism was accelerated significantly and dose-dependently up to $1,500 \mathrm{\mu M}$. It is unknown what sort of metabolites were produced in this acceleration. Benoxaprofen did not affect soybean 15-LO activity (15) and 12LO activity in the microsomal preparation of human platelets (16), but it showed an inhibitory effect on 5-LO in rabbit PMNs (10). guinea pig peritoneal cells, human promyelocytic leukemic cell line HL 60 (16) and rat basophil leukemia cells (RBL-1) (17). In accordance with these reports, in this study, benoxaprofen showed a marked inhibition of 5-LO in PMNs, a very weak inhibition of 12-LO in platelets and no inhibition of soybean 15-LO. Furthermore, it inhibited $\mathrm{CO}$ in PMNs markedly compared with other $\mathrm{CO}$ enzyme preparations. Benoxaprofen has a remarkable feature as an anti-inflammatory drugs because it showed a relatively selective inhibition on the arachidonic acid cascade in PMNs.

All the drugs tested except the NSAIDs mentioned above showed inhibitory effects on both $\mathrm{CO}$ and $\mathrm{LO}$ activities. Iron is a cofactor of $\mathrm{CO}$ and also probably an essential component of $L O$, and agents which form a chelate complex with ferric ions inhibit LO activity (18, 19). In this study, dithiol, a ferric ion chelating agent, showed inhibitory effects on both enzyme activities which were observed at almost the same range of concentrations. These results suggest that its inhibitory effects on both enzyme activities are probably based on its chelating action against ferric ions. NDGA showed a relatively selective inhibition of LOS in this study. These results are consistent with those of Harvey and Osborn (20) that NDGA had no effect on $\mathrm{CO}$, but selectively inhibited LO in guinea pig PMNs. APH inhibited soybean 15-LO markedly compared with the other enzymes tested. Ethoxyquin inhibited COs more markedly than LOs, and with regard to LO inhibition, it inhibited 5-LO in PMNs markedly.

Allen et al. (21) showed that human PMNs emitted $\mathrm{CL}$ during the process of phagocytosis and proposed that CL generated from PMNs reflected the generation of singlet oxygen. Oyanagui (22) demonstrated the participation of superoxide anions in the prostaglandin phase of rat carrageenan foot oedema, and it was reported that superoxide anion production in isolated guinea pig macropharges (23) and in guinea pig peritoneal exudate cells (24) was inhibited by NSAIDs. However in our study. NSAIDs failed to inhibit the generation of $C L$ from PMNs. Oyanagui $(23,24)$ recorded the decrease of $\mathrm{NADH}$ absorption at $340 \mathrm{~nm}$ which indicates the superoxide anion production and suggested that NSAIDs blocked superoxide radical production, but did not work as radical scavengers.

In our experiment. PMNs were activated by phorbolester, and direct light emission from PMNs was monitored by a liquid scintillation counter. So, the different results may reflect 
the differences in the experimental conditions, cell sources used and/or species of radicals concerned in each experimental system. In this study, only drugs which strongly inhibited 5-LO in PMNs showed an inhibitory activity on the generation of $\mathrm{CL}$. It should be noted, however, that the number of drugs investigated is small, and therefore. one has to await further investigations before this statement can be generalized. It is uncertain whether their inhibitory activities on CL generation were ascribed to radical scavenger effects or other inhibitory effects on any processes in the pathways of superoxide radical generation and subsequent CL generation.

\section{References}

1 Vane, J.R.: Inhibition of prostaglandin synthesis as a mechansm of action for aspirin like drugs. Nature New Biol. 231, 232-235 (1971)

2 Higgs, G.A., Eakins, K.E., Mugridge, K.G., Moncada, S. and Vane, J.R.: The effects of nonsteroid anti-inflammatory drugs on leukocyte migration in carrageenin-induced inflammation. Eur. J. Pharmacol. 66, 81-86 (1980)

3 Mikami, T. and Miyasaka, K.: Effects of several anti-inflammatory drugs on the various parameters involved in the inflammatory response in rat carrageenin-induced pleurisy. Eur. J. Pharmacol. 95, 1-12 (1983)

4 Bray, M.A., Cunningham, F.M., Ford-Hutchinson A.W. and Smith, M.J.H.: Leukotriene B: a mediator of vascular permiability. Br. J. Pharmacol. 72, 483-486 (1981)

5 Wedmore, C.V. and Williams, T.J.: Control of vascular permeability by polymorphonuclear leukocytes in inflammation. Nature 289, 646650 (1981)

6 Palmer, R.M.J., Stepney, R.J., Higgs, G.A. and Eakins, K.E.: Chemokinetic activity of arachidonic acid lipoxygenase poducts on leukocytes of different species. Prostaglandins 20, 41?-418 (1980)

7 Palmer, R.M.J. and Yeats, D.A.: Leukotriene B: $A$ potent chemotactic agent and stimulus for Iysosomal enzyme secretion for human neutrophils (PMN). Br. J. Pharmacol. 73, 260P-261 P (1981)

8 Bokoch, G.M. and Reed, P.W.: Effect of various lipoxygenase metabolites of arachidonic acid on degranulation of polymorphonuclear leukocytes. J. Biol. Chem. 256, 5317-5320 (1981)

9 Williams, T.J. and Piper, P.J.: The action of chemically pure SRS-A on the microcirculation in vivo. Prostaglandins 19, 779-789 (1980)

10 Walker, J.R. and Dawson, W.: Inhibition of rabbit PMN lipoxygenáse activity by benoxaprofen. J. Pharm. Pharmacol. 31, 778-780 (1979)

11 Vanderhoek, J.Y., Bryant, R.W. and Bailey, J.M.: 15-Hydroxy-5,8.11,13-eicosatetraenoic acid. A potent and selective inhibitor of platelet lipoxygenase. J. Biol. Chem, 255, 5996-5998 (1980)

12 Hurley, J.V., Ryan, G.B. and Friedman, A.: The mononuclear response to intrapleural injection in the rat. J. Pathol. Bacteriol. 91, 575-587 (1966)

13 Knippel, I., Baumann, J., von Burchhausen, F. and Wurm, G.: Interactions of sulfhydryl agents and soybean lipoxygenase inhibitors. Biochem. Pharmacol. 30, 1677-1684 (1981)

14 Baumann, J., von Bruchhausen. F. and Wurm, G.: A structure-activity study on the influence of phenolic compounds and bioflavonoids on rat renal prostaglandin synthetase. Naunyn Schmiedebergs Arch. Pharmacol. 307, 73-78 (1979)

15 Kingston, W.P.: 15-Lipoxygenase: a rapid sensitive assay for lipoxygenase inhibitor. Br. J. Pharmacol. 74, 919P-920P (1981)

16 Harvey, J., Parish, H., Ho, P.P.K., Boot, J.R. and Dawson, $W$ : The preferential inhibition of 5 lipoxygenase product formation by benoxaprofen J. Pharm. Pharmacol. 35, 44-45 (1983)

17 Levine, L.: Inhibition of the A-23187-stimulated leukotriene and prostaglandin biosynthesis of rat basophil ieukemia (RBL-1) cells by nonsteroidal anti-inflammatory drugs, anti-oxidants, and calcium channel blockers. Biochem. Pharmacol. 32, 3023-3026 (1983)

18 Pistorus, E.K. and Axelrod, B.: Iron, an essential component of lipoxygenase. J. Biol. Chem. 249, 3183-3186 (1974)

19 Aharony, D., Smith, J.B. and Silver, M.J.: Inhibition of platelet lipoxygenase by toluene3,4-dithiol and other ferric iron chelators. Prostaglandins Med. 6, 237-242 (1981)

20 Harvey, J. and Osborne, D.J.: A rapid method for detecting inhibitors of both cyclooxygenase and lipoxygenase metabolites of arachidonic acid. J. Pharmacol. Methods 9, 147-155 (1983)

21 Allen, R.C., Stjernholn, R.L. and Steele, R.H.: Evidence for the generation of an electronic excitation state(s) in human polymorphonuclear leukocytes and its participation in bactericidal activity. Biochem. Biophys. Res. Commun. 47. $679-684(1972)$

22 Oyanagui. Y.: Participation of superoxide anions at the prostaglandin phase of carrageenan foot- 
oedema. Blochem. Pharmacol. 25, 1465-1472 (1976)

23 Oyanagui, Y.: Inhibition of superoxide anion production in macrophages by anti-inflammatory drugs. Biochem. Pharmacol. 25, 1473-1480
(1976)

24 Oyanagui, $Y$ : Inhibition of superoxide anion production in non-stimulated guinea pig peri:oneal exudate cells by anti-inflammatory drugs. Biochem. Pharmacol, 27, 777-782 (1978) 